Print ISSN: 2233-4165 / Online ISSN: 2233-5382

doi:http://dx.doi.org/10.13106/ijidb.2018.vol9.no2.27.

\title{
A Study on Customer Satisfaction Factors of Supply Chain Management Support Center(SCSC)
}

\author{
Byung-Mo Coo*
}

Received: January 19, 2018. Revised: February 5, 2018. Accepted: February 15, 2018.

\section{Abstract}

\begin{abstract}
Purpose - This study centers on field surveys aimed at deriving the customer satisfaction factors of customer support centers that are positioned between suppliers and consumers in the supply chain. They consists of manufacturing, sales, distribution, consumption and collection, and that are in charge of core functions for suppliers' customer satisfaction management and consumers' satisfaction with consuming activities.

Research design, data, and methodology - The customer satisfaction factors of customer support centers were derived through literature review and expert opinion surveys, and a questionnaire was developed through a process of the refinement of variables using pilot tests and 330 questionnaire sheets were distributed. The questionnaire sheets were collected and opinions in them were analyzed using fuzzy AHP methodology.

Results - Three factors, which are turnover intentions, motivation, and job satisfaction, were derived as customer satisfaction factors of customer support centers, and the ranking relationships of these three factors were analyzed. In addition, the ranking relationships among six execution variables of turnover intentions, 10 execution variables of motivation, and 10 execution variables of job satisfaction were analyzed using fuzzy AHP methodology to obtain quite significant results. Based on the results of this study, three implications in the three strategic aspects and an implication in the academic aspects are presented.

Conclusions - Motivation and job satisfaction, job satisfaction and turnover intentions, and motivation and turnover intentions are not formed by independent or different factors or environments. They are in the same context with each other (maintaining high correlations) and are in the relationships of virtuous circles in which they complement each other.
\end{abstract}

Keywords: Customer Satisfaction Factors, Job Satisfaction, Turnover Intention, Motivation, MOT.

JEL Classifications: C33, C42, D3, I3, J63.

\section{Introduction}

Customer support centers are positioned between suppliers, who are manufacturers or distributors, and consumers such as enterprises and individuals that purchase goods from the suppliers in a supply chain in which a series of processes such as the manufacturing, distribution, and consumption of tangible and intangible products occur, along with and feedback on them, (Bradley \& Sparks, 2012; Bobocel \& Zdaniuk, 2005; Shaw et al., 2003) and are in charge of core functions in supply chain management (SCM) as value windows (Coo, 2010) for database marketing to satisfy customers and induce repurchasing (Bradley \&

* Assistant Professor, Dept. of International Business and Management, Hansei University, Korea.

Tel: +82-31-450-9813, E-mail: bmcoo@hansei.ac.kr
Sparks, 2012; Bobocel \& Zdaniuk, 2005; Shaw et al., 2003) through emotional labor (Morris \& Feldman, 1996; Ashforth \& Humphrey, 1993) using CTI, ICT, SNS, etc. as means.

The customer support centers that are in charge of core functions in the supply chain processes of tangible and intangible products should be approached from the perspective of the workers who constitute the customer support centers. Although mechanized means such as CTI, ICT, and SNS are used to respond to customer requirements or opinions, the main agents that deal with customers are persons that cannot be replaced with automated mechanical means, and we call these workers callers. In addition, phone calls account for at least $90 \%$ of the mechanical means used by these callers to respond to customers and in the processes of responses, the callers not only face handling of a high number of calls per hour $(\mathrm{CPH})$, 
but are also exposed to highly intensive emotional labor.

Emotional labor refers to a new type of wage labor provided to customers that is not a form of labor in terms of mind or body (Hochschild, 1983). It refers to emotional activities such as bearing, suppressing, controlling, or managing emotions that are conducted in public spaces where superiors, colleagues, and subordinates exist, instead of private spaces, and have the nature of exchange values transacted by receiving wages (Grandey, 2000; Ashforth \& Humphrey, 1993; Gross, 1988).

The emotional laborers who work in customer support centers are callers. They are engaged in one of the representative occupations that require emotional labor, and they are characterized by the fact that they are engaged in their jobs while suppressing and controlling their personal emotions to meet the purpose or demand of their organizations. This can be expressed as the commercialization of human emotions, through which the input of emotions becomes part of labor and the labor that manages emotions becomes an element of product value (Kim et al., 2012; Hochschild, 1983). The callers, who are emotional laborers, play the role of satisfying suppliers and consumers between suppliers and consumers as their first purpose. In reality, they suffer from mental tension and stress because they bear the moment of truth (MOT) to respond to customers on behalf of suppliers during every call. Paradoxically, they may satisfy or dissatisfy customers depending on their internal roles and external expressions.

The purpose of this study is to derive the customer satisfaction factors of customer support centers that are in charge of core functions in the supply chain. In customer support centers, the entities that determine the satisfaction and dissatisfaction of suppliers, who are internal customers of the organization, and consumers, who are external customers, are the callers, and they are emotional labor workers that are closely correlated with the customer satisfaction factors of customer support centers and are core study subjects necessary to obtain the results of this study.

To that end, three factors, job satisfaction, motivation, and turnover intentions, which enable emotional laborers to play their role satisfactorily, were derived through literature review and face-to-face interviews with customer support center workers. The goal of this study is to analyze the ranks and the degrees of influence among the three factors that act as the satisfaction factors of customer support center customers derived through the process and study the types of execution variables of the three factors and the ranking relationships among them.

\section{Literature Review}

\subsection{Customer support center}

Customer support centers, which are also called various other names such as customer satisfaction center, customer center, call center, and counseling center (Suh \& Lee, 2016) use computer telephony integration (CTI) such as phone calls, e-mails, and faxes and information communication technology (ICT) such as social network services (SNS) as means of communication. Customer support centers require emotional labor, that is, expressing appropriate emotions according to situations using voices, facial expressions, and body expressions (Morris \& Feldman, 1996; Ashforth \& Humphrey, 1993). Customer support centers are non-faceto-face, interactive communication environments where tangible and intangible products are introduced, reservations for the foregoing products are accepted, dissatisfaction is accepted and resolved, simple complaints and dissatisfaction are resolved, and questions and answers about products are handled, and they are also core supply chain members in supply chain management that provide easy and convenient access to information thereby, providing customer benefits as well as value windows, and the vertices of value warehouses in consumer DB marketing that are contacting consumers, obtaining information, and responding to consumers(Coo, 2010).

\subsection{Customer satisfaction}

The service quality defined as an aggregate of service outcomes that determines the satisfaction levels of service users is customer satisfaction (Miriam, 2016; ITU, 1995). It has a characteristic that it can be identified only when the indicators established to reflect customers' expectation levels have been quantitatively evaluated (Veber, 2000). Workers' job satisfaction and high self-efficacy make good service contacts to produce good outcomes, which lead to customer satisfaction (Tang \& Chang, 2010; Hartline \& Ferrel, 1996). Service failure and customer dissatisfaction resulting from dissatisfaction with services, poor customer reception by workers, negative words, and flip-flopping have been proved in many studies (Wang et al., 2014; Mikael, 2013; Swanson \& Kelley, 2001). In the case of service failure, excuses and justifications intended to recover from failure are not helpful for customer satisfaction (Arun et al., 2016), and since it is due to the negative characteristics of excuses (Tax et al., 1998), sufficient logical explanations and apologies are helpful for inducing customer satisfaction and repurchases (Bradley \& Sparks, 2012; Bobocel \& Zdaniuk, 2005; Shaw et al., 2003). In addition, the service quality of customer support centers and callers' satisfaction act positively on service performance and customer satisfaction to not only increase reuse intentions (Lee \& Kim, 2015; Kim, 2007), but also to form quality-satisfaction level-loyalty chains, thereby directly affecting the profitability of enterprises (Oliver, 1997, 1999). That is, customer satisfaction acts as an important indicator in terms of accounting (Johnson, 2001). 


\subsection{MOT}

The moment of truth(MOT) can be translated into customer contact, service contact, etc. It is defined as a time cycle through which the customer directly contacts and interacts with a supplier's goods and services (Zeithaml \& Bitner, 1996; Zeithaml et al., 1996; Suprenant \& Solomon, 1987; Shostack, 1985). The MOT can be divided into a first one and second one. The caller should be able to attract the customer in the first MOT and should be able to draw satisfaction in the second MOT (Martin, 2008). In the case of products, the first MOT should be the stage where the consumer enters a shop with a shopping cart to see the state of packaging (Silayoi \& Speece, 2004, 2007), in the case of services, it should be the appearance of the employee who faces the customer, such as his/her clothing, hair, facial expression, etc., and in the case of customer support center callers, it should be the greetings and guiding words to customers such as the greeting words and voice volumes and tones. The second MOT is the result realized when customers have experienced products or services (Löfgren, 2005).

\subsection{Job satisfaction}

Job satisfactions, defined as the attitude of employees to think positively about their jobs (Robbins \& Judge, 2013), not only motivates organization members to promote productivity in internal and external aspects (Dennis, 2017; Ayers, 2015) but is also closely correlated with job performance (Judge, 2001; Laffaldano \& Muchinsky, 1985). It can be best predicted by compensation and cost value (Farrell \& Rusbult, 1981) and is also related to pay satisfaction, gender, and manager status (Weaver, 2015). In particular, emotional workers, whose job mostly involves interpersonal relationships, often face role conflicts and role ambiguities that affect job satisfaction levels, self-efficacy, and adaptability to service jobs (Abdul et al., 2017). The two are sorts of role stress (Nugroho, 2012; Robbins, 2002) and are expressed as role conflicts occurring due to unclear roles and responsibilities and role collision occurring due to discrepancies between the requirements for two roles performed simultaneously against the organization's expectations and demands, respectively (Zorlu, 2012). Both reduce the worker's confidence in his/her ability and bring about low job satisfaction levels. Therefore, to enhance the job satisfaction of employees, it is important to provide the employees with things equal to what is expected by them when they are in good emotional states or in their jobs (Moumtzoglou, 2010; Le Rouge et al., 2006), because callers' job satisfaction improves the quality of customer service (Choi \& Lee, 2009). Positive influence factors that improve the job satisfaction of emotional laborers such as customer support center callers also include the quality of information systems and low turnover intentions (Lee \& Son,
2016; Park et al., 2015).

\subsection{Turnover intention}

Career changes are defined as voluntary movements of individuals across the boundary between the members of different social systems (Gaertner, 1999; Price, 1997), and many scholars have investigated voluntary turnovers (Kim et al., 2017; Hom \& Griffeth, 1995; Lee \& Mitchell, 1994). Age and experience are positively correlated with turnover intentions, and turnovers are shown to be particularly high among new employees (Cho \& Lewis, 2012). In addition, the net call time of callers working in customer support centers not only causes job stress but also negatively affects service quality (Suh \& Lee, 2016). The emotional and sentimental exhaustion, depersonalization, role ambiguity, and declines in self-fulfillment of callers also increase turnover intentions, and modest vertical communication with superiors plays the role of reducing turnover intentions (Lee \& Son, 2016; Kim \& Jung, 2015). In particular, a study reported that higher work demand and lower work autonomy, which are factors that affect the turnover intentions of callers working in customer support centers, are associated with higher turnover intentions (Shin et al., 2015).

On the contrary, the reliability of managers has long been studied as an important factor in the aspect of management because of its function to reduce turnover intentions (Yang, 2005; Vigoda \& Yuval, 2003; Nyhan, 2000) since it affects not only members' satisfaction levels, cooperation, and maintenance of positive relationships (Cho \& Lee, 2011), but also performance improvement and affirmation in the internal aspect (Newell et al., 2008; Rynin et al., 2004). Employees who participate in internal activities are the most powerful supporters or the loudest critics, depending on the situation (Waters et al., 2013), and have been regarded as one of the most important strategic factors as human resources (Kim \& Rhee, 2011; Grunig et al., 2002; Grunig, 1992). Since employees' career changes and turnover intentions may lead to the loss of such a strategic resource, actions to increase employee participation and support their communications may be reinforced to reduce turnover intentions (Kang \& Sung, 2017). In addition, productivity in the internal and external aspects should be increased and career changes and turnover intentions should be reduced through members' job satisfaction (Dennis, 2017; Bertelli, 2007).

\subsection{Motivation}

The aggregate of feelings about selection and actions, which is the stimulus and action energy to conduct a certain action, is called a motive (Mitchell et al., 2012; Phillips, 2004), and motivation refers to the desire to make efforts to pursue the goals of the organization (Stephen, 1996). Job performance and customer performance positively affect intrinsic motivation (Park et al., 2012; Yoon, 2009), and job 
satisfaction levels and modern communication that can be easily shared become the means of motives to reduce the possibility of employees' career changes and raise their satisfaction levels (Pam Goncalves, 2017). In addition, trust in superiors strengthens members' intrinsic motivation to contribute to the active sharing of knowledge and creative behaviors (Kim, 2015), and the sense of belonging, mutual trust and thanks, and open interactions among colleagues induce the members to devote themselves to the organization (Mai-Stiina et al., 2017). Furthermore, employees' communicative behaviors (ECB) based on trust are management properties that serve strategic functions in terms of the enterprise (Lee \& Kim, 2017; Shen and Kim, 2012; Edwards, 2010; Potter, 2010; Molleda \& Roberts, 2008; Bishop, 2003), and such results contribute to motivation to build up trust with employees.

\section{Analysis of Customer Satisfaction Factors of SCSC}

\subsection{Survey design}

This survey was conducted with callers, who are emotional laborers working in customer support centers in the service industry, using a structured questionnaire designed in advance. Four enterprises participated in the survey and the number of callers who completed the questionnaire was 330. The details of the design of the survey are as shown in <Table $1>$.

$<$ Table 1> Design of survey of SCSC satisfaction factors

\begin{tabular}{|c|l|}
\hline Classification & \multicolumn{1}{|c|}{ Contents } \\
\hline Parent population & Service industry enterprises \\
\hline Survey method & Mobile survey, face to face survey \\
\hline Survey area & Capital area(Seoul orientation) \\
\hline Survey sample & 330 callers by target approach extraction \\
\hline Valid sample & 165 callers \\
\hline Questionnaire & $\begin{array}{l}\text { Structured open and close type } \\
\text { questionnaire }\end{array}$ \\
\hline
\end{tabular}

\subsection{Result of analysis}

\subsubsection{Study process and methodology}

\subsubsection{Study process and model}

This study was conducted with actual industries and business types that require emotional labor using the following process and study model. First, expert opinion surveys were conducted with workers in the customer support center industry to gain insights and understand the characteristics of the business type. Second, theories studied previously were examined to derive three customer support center satisfaction factors (turnover intention, job satisfaction, and motivation). Third, to secure the internal and external validity of the structured questionnaire, which is a survey medium, operational definitions of the three factors, turnover intention, job satisfaction, and motivation, were established and a questionnaire was prepared for measurement of the three factors. Fourth, a pilot test was conducted to find out the respondents' responses to and opinions about the contents, readability, and difficulty of the questionnaire prepared, and the questionnaire was finalized after eliminating the weak points obtained from the pilot test and reflecting the results in the refinement of the contents. Finally, the completed questionnaire was distributed, collected, edited and encoded to complete a study model to derive study results using fuzzy AHP.

\subsubsection{Fuzzy AHP Methodology}

The fuzzy AHP methodology used in this study is an analysis technique in which fuzzy theory is applied to AHP, as proposed by Laarhoven and Pedrycz (1983).

Fuzzy theory was introduced in 1965 when Professor Lotfi A. Zadeh published a paper titled "Fuzzy Sets." This theory is used as an analysis technique in many studies in South Korea, too. It is a representative one among the methodologies that are frequently used when qualitative linguistic contents are expressed with quantitative values, and it provides a theoretical background for processing ambiguous expressions. That is, unlike numbers, languages often contain many pieces of information in a single word. In such a case, the language contains ambiguous information. This theory provides a theoretical basis for logical processing of the information contained in the language. In other words, they accept subjective points of view, unsafe data, qualitative measurements and experience. The characteristics of fuzzy theory are as shown in $<$ Table $2>($ Coo,2010).

<Table 2> Differences between existing and fuzzy theory

\begin{tabular}{|c|c|c|}
\hline Division & Existing science & Fuzzy theory \\
\hline Viewpoint & Objectivity & Recognizes subjectivity \\
\hline Data & Accuracy & $\begin{array}{c}\text { Recognizes } \\
\text { incompleteness and } \\
\text { ambiguity }\end{array}$ \\
\hline Theory & $\begin{array}{c}\text { Mathematical, theoretically } \\
\text { strict }\end{array}$ & May not be strict \\
\hline Measurement & Quantitative & $\begin{array}{c}\text { Includes qualitative } \\
\text { parts }\end{array}$ \\
\hline Noise & $\begin{array}{c}\text { Remove for as long as } \\
\text { possible }\end{array}$ & $\begin{array}{c}\text { Recognizes to some } \\
\text { extent }\end{array}$ \\
\hline Experience & $\begin{array}{c}\text { Remove for as long as } \\
\text { possible }\end{array}$ & Utilizable \\
\hline
\end{tabular}

In addition, the (AHP), proposed by Professor Thomas L. Saaty in 1980, is a decision-making analysis technique that expresses problems with complex interrelations in a hierarchical structure, qualitatively and subjectively compares 
the relationships between elements to determine the relative importance of each element and alternative, and provides ranking relationships among problem solutions (Harker, 1989). It is also frequently used as a solution tool for resource allocation, the solution of complex decision-making problems, and analysis of effects in comparison with input costs (Saaty \& Vargas, 1982).

Since the AHP analyzes and utilizes the results of pairwise comparisons by evaluators, its reliability is dependent on these results. However, the judgment of decision makers comes to involve ambiguity and uncertainty. Fuzzy theory (Zadeh, 1965) enables relatively easy processing of such qualitative evaluation criteria that cannot be easily processed in decision-making problems but should be reflected without fail. The fuzzy AHP methodology (Yoon \& Choi, 2011) effectively applied such a fuzzy theory to the AHP.

In the case of normal sets, whether factors belong to the sets or not can be clearly judged. However, factors in fuzzy sets have ambiguous boundaries so that the boundary between belonging to and not belonging to a certain subset is not clear, but gradually changes. That is, fuzzy theory expanded the concept of $[0,1]$, which is a two-valued scale of 1 , into the concept of an infinitely multiple-valued scale $[0,1]$, which means at least 0 but not larger than 1 .

When $\mathrm{X}$ is assumed to be a space of factor $x$, one fuzzy set $A$ in $X$ has each factor $X$ in $X$, and in this case, if membership function $\mu A(x)=1$ it means that $X$ completely belongs to $A$, while $\mu A(x)=0$ means that $\chi$ does not belong to $A$ at all. In other cases, $0<\mu A(x)<1$ means that $x$ partially belongs to $A$. When the value of $\mu A(x)$ is close to 1 , the degree to which $X$ belongs to $A$ is high. The membership function $\mu \mathrm{A}$ of the fuzzy set $A$ in the entire space $X$ is as follows.

$$
\mu A: \rightarrow[0,1]
$$

In general, triangular fuzzy numbers are widely used because of the efficiency of calculation and ease of data acquisition. This is shown in Figure (A1, a2, a3) in <Figure $1>$, and the membership function $\mu \mathrm{A}$ is as follows. As shown in <Figure 1>, a triangular fuzzy number consists of three values (a1, a2, a3) and the membership function $\mu \mathrm{A}$ is as follows.

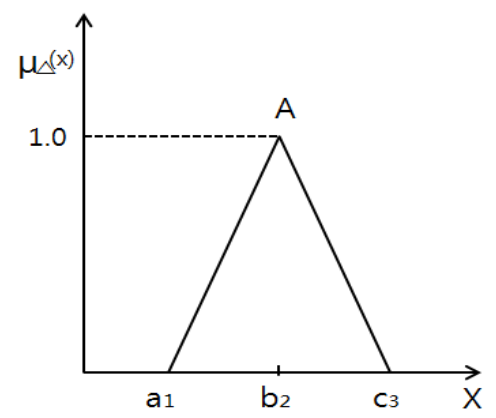

$$
\mu A(x)=\left\{\begin{array}{lc}
0, & x<a_{1} \\
\frac{x-a_{1}}{a_{2}-a_{3}}, & a_{1 \leq x \leq a_{2}} \\
\frac{a_{3-x}}{a_{3-a_{2}},} & a_{2 \leq x \leq a_{3}} \\
0, & x>a_{3}
\end{array}\right.
$$

<Figure 1> Triangular fuzzy number and membership function

The Ith fuzzy number out of $n$ membership functions is as follows.

$$
\widetilde{A}=\left(a_{1}^{(i)}, a_{2}^{(i)}, a_{3}^{(i)}\right), i=1,2,3, \ldots \ldots \ldots, n
$$

The average triangular fuzzy number (fuzzification or fuzzy number) $\tilde{A}$ is indicated as follows.

$$
\begin{aligned}
\widetilde{A} & =\text { Aave }=\frac{\widetilde{A_{1}}+\widetilde{A_{2}}+\ldots+\widetilde{A_{n}}}{n} \\
& =\frac{\left(\sum_{i=1}^{n} a_{1}^{(i)}, \sum_{i=1}^{n} a_{2}^{(i)}, \sum_{i=1}^{n} a_{3}^{(i)}\right.}{n}=\left(a_{1}, a_{2}, a_{3}\right)
\end{aligned}
$$

Zadch emphasized that the strength of fuzzy theory is that it can quantify linguistic variables. Language variables are ones of which the values are not numbers but are in the form of a general or artificial language, which is measured in words or sentences. Language variables can be shown as a single fuzzy set. <Figure 2> shows triangular membership functions for the measured values [very bad to very good] of language variables (Negoita et al., 1978).

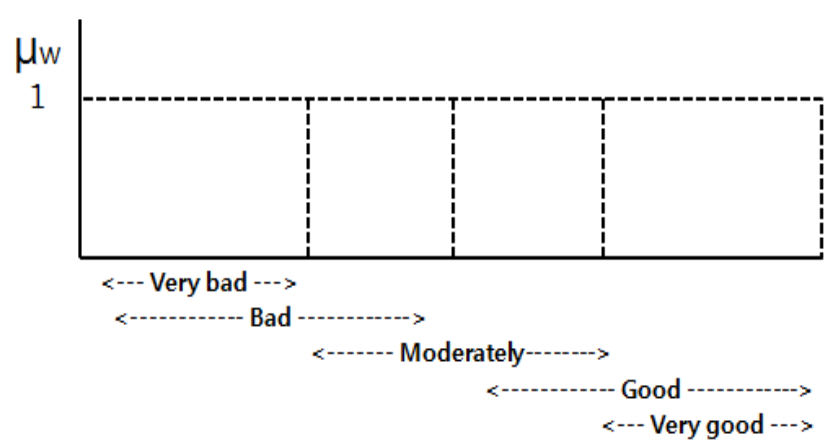

<Figure 2> Triangular membership functions of language

$<$ Table 3> shows the scales obtained by converting the language expressions used in the AHP pairwise comparison into triangular fuzzy numbers. 
<Table 3> Triangular scale conversion scale

\begin{tabular}{|c|c|c|}
\hline Language scale & $\begin{array}{c}\text { Triangular fuzzy } \\
\text { scale }\end{array}$ & $\begin{array}{c}\text { Inverse Triangular } \\
\text { fuzzy scale }\end{array}$ \\
\hline The same & $(1,1,1)$ & $(1,1,1)$ \\
\hline A little important & $(1 / 2,1,3 / 2)$ & $(2 / 3,1,2)$ \\
\hline Moderately important & $(1,3 / 2,2)$ & $(1 / 2,2 / 3,1)$ \\
\hline Quite important & $(3 / 2,2,5 / 2)$ & $(2 / 5,1 / 2,2 / 3)$ \\
\hline Very important & $(2,5 / 2,3)$ & $(1 / 3,2 / 5,1 / 2)$ \\
\hline Absolutely important & $(5 / 2,3,7 / 2)$ & $(7 / 2,1 / 3,2 / 5)$ \\
\hline
\end{tabular}

\subsubsection{Ranking relationships of SCSC's customer satisfaction factors}

The rankings among three customer satisfaction factors of SCM customer support centers(SCSCs), which are customer satisfaction, motivation, and turnover intentions, were analyzed. The number one was shown to be "turnover intentions," defined as whether the respondent would work continuously in the workplace he/she is currently working in, or work only until the near future or until work conditions were acceptable. Number two was "motivation," defined as whether the current job is helpful for one's livelihood and the future, sense of accomplishment, compliments for work performance, fair opportunities for promotion, and the level of satisfaction with material and monetary compensations. Number three was "job satisfaction," defined as satisfaction with welfare, wages, education and training, trust in and cooperation with colleagues, relationships with superiors, equipment and facilities, working hours, and work environments <see Table 4>.

\subsubsection{Ranking relationships among execution variables that affect turnover intentions}

Among the variables for turnover intentions measured with the six execution variables, the results of analysis indicated that the number one variable was "I sometimes think about submitting my resignation," number two was "If another company paid higher wages, I would immediately move to that company," and number three was "I will find a new job shortly." These results can be regarded as indicating that career changes are based on voluntary intentions, as shown by the results of studies conducted by Kim et al. (2017), Hom and Griffeth (1995), and Lee and Mitchell (1994). Similarly, turnover can be seen as showing the willingness of the worker to volunteer. On the other hand, number five and number six were whether the members are regarded as the enterprise's human resources and whether the members are enabled to be satisfied with their jobs, which can be said to be results indicating the importance of non-voluntary environments, as shown by the results of studies conducted by Kang and Sung (2017), Dennis (2017), and Bertelli (2007).

\subsubsection{Ranking relationships among execution variables} that affect motivation

Among the execution variables of the factor motivation, the number one variable was shown to be "Officially dining together with colleagues is helpful to work life," number two was "Communication with the surrounding people in the department is smooth," and number three was "I am praised by the surrounding people for my ability and efforts to handle my job." These results indicate that number one through number three variables were similar to the results of study conducted by Mai-Stiina et al. (2017), indicating that devote themselves to the organization." Variable number four coincides with the concept of motives, "stimuli and action energy to conduct certain actions," indicated by the results of studies conducted by Mitchell et al. (2012) and Phillips (2004), and variable number five coincides with the results "The sense of belonging, mutual trust, appreciation, and open interactions among colleagues make the members a of studies conducted by Park et al. (2012) and Yoon (2009), indicating that "job performance positively affects intrinsic motivation" and the results of a study conducted by Pam Goncalves (2017), indicating that "job satisfaction reduces

<Table 4> Result of fuzzy AHP analysis of SCM customer satisfaction factors

\begin{tabular}{|c|c|c|c|cc|c|c|}
\hline Factors & Low & Middle & High & Total & G-Factor & Ranking \\
\hline Turnover intention & 26.9 & 41.4 & 52.7 & 0.48 & 0.740 .94 & 0.725 & 1 \\
\hline Motivation & 26.7 & 41.0 & 53.0 & 0.480 .730 .95 & 0.722 & 2 \\
\hline Job satisfaction & 27.2 & 41.0 & 52.2 & 0.350 .600 .86 & 0.721 & 3 \\
\hline
\end{tabular}

$<$ Table 5> Result of analysis of execution variables that affect turnover intention

\begin{tabular}{|c|c|c|c|c|c|c|c|c|}
\hline Factor 1 & Low & Middle & High & \multicolumn{3}{|c|}{ Total } & G-Factor & Ranking \\
\hline I sometimes think about submitting my resignation. & 22.3 & 36.9 & 49.9 & 0.40 & 0.66 & 0.89 & 0.652 & 1 \\
\hline $\begin{array}{l}\text { If another company paid higher wages, I would } \\
\text { immediately move to that company. }\end{array}$ & 19.7 & 34.7 & 48.1 & 0.35 & 0.62 & 0.86 & 0.613 & 2 \\
\hline I will find a new job shortly. & 14.7 & 29.5 & 44.5 & 0.26 & 0.53 & 0.79 & 0.528 & 3 \\
\hline I don't know well. & 14.7 & 29.3 & 44.0 & 0.26 & 0.52 & 0.79 & 0.524 & 4 \\
\hline I will work here only until I find another job. & 13.3 & 28.8 & 43.6 & 0.24 & 0.51 & 0.78 & 0.511 & 5 \\
\hline I will continuously work at the current company. & 11.2 & 26.7 & 42.1 & 0.20 & 0.48 & 0.75 & 0.476 & 6 \\
\hline
\end{tabular}


the possibility of changing a job and improves employee satisfaction." In addition, variable number six is similar to the results of a study conducted by Kim (2015) indicating that 'trust in superiors strengthens members' intrinsic motivation to contribute to the active sharing of knowledge and creative behaviors." The fact that some of the results of this study are identical or similar to the results of previous studies can be said to show that the root causes of motivation are maintained even when time has passed and environments have been changed. (See <Table 6> for variables 7 th to 10 th).

\subsubsection{Rank relationships among execution variables} that affect job satisfaction

As shown in $\langle$ Table $7>$, job satisfaction factors were measured with 10 execution variables, and the results indicate that the top three execution variables have relatively larger effects on job satisfaction compared to the remaining seven variables because their g-factor values are at least $28.9 \%$ higher than those of the remaining seven execution variables. To review the three variables, number one was shown to be "I trust colleagues who perform the job together with me," number two was "Colleagues help each other with difficulties that occur while the job is performed," and number three was "Superiors provide the information necessary to perform the job." The number one and two variables involve attributes that explain the factors that affect motivation obtained from previous studies: "The sense of belonging, mutual trust, appreciation, and open interactions among colleagues make the members devote themselves to the organization" (Mai-Stiina et al., 2017), "age and experience are positively correlated with turnover intentions" derived from the examination of the theory of turnover intentions (Cho \& Lewis, 2012), and "reinforcement of communication reduces turnover intentions" (Kang \& Sung, 2017; Bertelli, 2007). The number three variable was also shown to be correlated with "modest communication with superiors" that reduces turnover intentions (Lee \& Son, 2016; Kim \& Jung, 2015). These study results can be said to be very important as they show that motivation, job satisfaction, and turnover intentions are not formed by independent or different factors or environments, but are in a relationship of virtuous circles in which they are in the same context with each other and complement each other. Variables four through 10 show study results generally similar to the results of previous studies described above (Lee \& Son, 2016; Kim \& Jung, 2015; Park et al., 2015; Weaver, 2015; Judge, 2001; laffaldano \& Muchinsky, 1985; Farrell \& Rusbult, 1981) (see 2.3, Job satisfaction).

<Table 6> Result of analysis of execution variables that affect motivation

\begin{tabular}{|c|c|c|c|c|c|c|c|c|}
\hline Factor 2 & Low & Middle & High & & Total & & G-Factor & Ranging \\
\hline Officially dining together with colleagues is helpful to work life. & 19.6 & 33.4 & 48.8 & 0.35 & 0.60 & 0.87 & 0.604 & 1 \\
\hline Communication with the surrounding people in the department is smooth. & 19.3 & 32.5 & 48.5 & 0.34 & 0.58 & 0.87 & 0.593 & 2 \\
\hline $\begin{array}{l}\text { I am praised by the surrounding people for my ability and efforts to handle } \\
\text { my job. }\end{array}$ & 14.7 & 29.6 & 45.3 & 0.26 & 0.53 & 0.81 & 0.532 & 3 \\
\hline The current job will be helpful for my future personal development. & 15.0 & 29.4 & 44.5 & 0.27 & 0.53 & 0.79 & 0.528 & 4 \\
\hline Evaluation and the system of compensation for evaluation results are helpful. & 14.0 & 27.7 & 42.9 & 0.25 & 0.49 & 0.77 & 0.501 & 5 \\
\hline I am satisfied with superiors' orders and work supervision. & 12.6 & 26.9 & 42.3 & 0.23 & 0.48 & 0.76 & 0.485 & 6 \\
\hline I feel a sense of accomplishment in my current job. & 12.2 & 27.1 & 42.1 & 0.22 & 0.48 & 0.75 & 0.484 & 7 \\
\hline I feel that opportunities for promotion are fairly guaranteed. & 12.5 & 25.8 & 41.3 & 0.22 & 0.46 & 0.74 & 0.471 & 8 \\
\hline I think my current job is stable for my livelihood. & 9.2 & 24.0 & 39.0 & 0.16 & 0.43 & 0.70 & 0.429 & 9 \\
\hline I am satisfied with the current monetary incentive system. & 5.7 & 17.2 & 32.1 & 0.10 & 0.31 & 0.57 & 0.323 & 10 \\
\hline
\end{tabular}

$<$ Table 7> Result of analysis of execution variables that affect job satisfaction

\begin{tabular}{|c|c|c|c|c|c|c|c|c|}
\hline Factor 3 & Low & Middle & High & & Total & & G-Factor & Ranking \\
\hline I trust colleagues who perform the job together with me. & 23.6 & 37.3 & 51.8 & 0.42 & 0.67 & 0.93 & 0.670 & 1 \\
\hline Colleagues help each other with difficulties that occur while the job is performed. & 23.2 & 36.9 & 51.2 & 0.41 & 0.66 & 0.91 & 0.662 & 2 \\
\hline Superiors provide the information necessary to perform the job. & 20.7 & 35.5 & 49.1 & 0.37 & 0.63 & 0.88 & 0.629 & 3 \\
\hline The company systematically provides job-related education and training. & 12.3 & 27.3 & 42.5 & 0.22 & 0.49 & 0.76 & 0.488 & 4 \\
\hline The work space is suitable for number of employees. & 10.8 & 25.0 & 39.9 & 0.19 & 0.45 & 0.71 & 0.450 & 5 \\
\hline The equipment and facilities are satisfactory for the performance of the job. & 8.7 & 23.3 & 38.3 & 0.16 & 0.42 & 0.68 & 0.418 & 6 \\
\hline The work hours are appropriate. & 8.7 & 23.8 & 37.9 & 0.16 & 0.43 & 0.68 & 0.421 & 7 \\
\hline The work environment is satisfactory for the performance of the job. & 7.9 & 23.3 & 38.0 & 0.14 & 0.42 & 0.68 & 0.413 & 8 \\
\hline The welfare benefits I am receiving are appropriate. & 5.2 & 18.6 & 31.7 & 0.09 & 0.33 & 0.57 & 0.331 & 9 \\
\hline I am satisfied with the wage in comparison with the effort I provide to the company. & 5.1 & 16.2 & 30.2 & 0.09 & 0.29 & 0.54 & 0.303 & 10 \\
\hline
\end{tabular}




\section{Conclusion}

\subsection{Discussion}

This study centered on field surveys aimed at deriving the customer satisfaction factors of customer support centers that are positioned between suppliers and consumers in the supply chain consisting of manufacturing, sales, distribution, consumption and collection, and that are in charge of core functions for suppliers' customer satisfaction management and consumers' satisfaction with consuming activities.

Whether customers that require tangible after-sales services such as repairs and exchanges or intangible after-sales services such as the expression of dissatisfaction and inquiries regarding products from customer support centers such about repairs are satisfied with consuming activities before and after purchase can be determined by the callers that constitute customer support centers and provide emotional labor. Therefore, there cannot be too many studies on them in terms of customer satisfaction management.

This study was conducted focusing on three factors of callers working at SCM customer support centers(SCSCs), which are job satisfaction, motivation, and turnover intentions. The ranking relationships among execution variables constituting the three factors, six execution variables (measurement variables) of job satisfaction, 10 execution variables of motivation execution, and 10 execution variables of turnover intentions were analyzed using fuzzy AHP, and the following results were obtained.

First, the ranking relationships of the effects of the three customer satisfaction factors, job satisfaction, motivation, and turnover intentions of SCSCs on customer satisfaction were analyzed and in the results, turnover intentions were shown to be number one with the highest g-factor value of 0.725 . Number two was motivation, with a g-factor value of 0.722 , and number three was job satisfaction, with a g-factor value of 0.721 . G-factor values closer to 1 mean larger effects, and all the factors showed degrees of effects exceeding $72 \%$.

Second, the ranking relationships among the six execution variables that constitute turnover intentions that have the largest effects on customer support centers' customer satisfaction among the three factors were analyzed, and the results indicated that variables one through five had g-factor values exceeding $50 \%$ (see <Table $5>$ for detailed ranking relationships among the execution variables).

Third, the ranking relationships among the 10 execution variables that constitute motivation that have the second-largest effects on customer support centers' customer satisfaction among the three factors were analyzed. The results indicated that five variables had degrees of effects exceeding $50 \%$, and the one with the highest degree of effects was shown to have a g-factor value of 0.604 (see
$<$ Table 6> for detailed ranking relationships among the execution variables).

Fourth, the ranking relationships among the 10 execution variables that constitute job satisfaction that have the third-largest effects on customer support centers' customer satisfaction among the three factors were analyzed. Among the 10 variables, three had degrees of effects exceeding $50 \%$, and all of them had g-factor values exceeding $62 \%$ (see $<$ Table $7>$ for detailed ranking relationships among the execution variables).

\subsection{Implication and future research}

The results of this study show the following three strategic implications in terms of customer support center operation.

First, the results of analysis of ranking relationships among three SCM customer support center(SCSC) customer satisfaction factors using the fuzzy AHP clearly show two characteristics: first, that g-factor values are hardly different among the different ranks, and second, that all the g-factor values exceed $72 \%$. That is, the difference in g-factor values between turnover intentions, which is number one, and motivation, which is number two, is 0.003 or $0.4 \%$, and the difference between the number two variable and number three variable, job satisfaction, is only 0.004 or $0.5 \%$. This means that these three factors are the customer satisfaction factors of customer support centers that are core supply chain members as well as value windows and the vertices of value warehouses in consumer DB marketing, and all of them are important. In addition, the study results in which all three factors identically have g-factors exceeding $72 \%$ indicate that the turnover intentions, motivation, and job satisfaction of callers that provide emotional labor in customer support centers have secured representativeness as customer satisfaction factors of SCSCs.

Second, six execution variables that affect turnover intentions were analyzed, and according to the results, four of the variables had g-factor values exceeding $50 \%$. One common feature is that all of them can be superficially judged to be voluntary turnover intentions (Kim et al., 2017; Hom \& Griffeth, 1995; Lee \& Mitchell, 1994). However, among them, the number one variable, "I sometimes think about submitting my resignation," and number two, "If another company paid higher wages, I would immediately move to that company," are voluntary turnover intentions resulting from a lack of vertical communication with superiors (Lee \& Son, 2016; Kim \& Jung, 2015) or a lack of maintenance of positive relationships with colleagues (Cho \& Lee, 2011) that can be prevented through satisfaction with compensation and pay (Weaver, 2015; Farrell \& Rusbult, 1981). This means that most of the voluntary turnover intentions $(60 \%$ when analyzed based on <Table $5>$ ) are not from pure voluntary motives of emotional laborers but are due to causes in the organization, and that the organization 
can remove approximately $60 \%$ of turnover intentions by removing such causes.

Third, 10 execution variables that affect motivation were analyzed, and according to the results, five variables had g-factor values exceeding $50 \%$. Among them, the number one and number two variables show close correlations with three execution variables of job satisfaction with g-factor values exceeding $50 \%$, indicating that organizations should ensure that mutual trust and open interactions with colleagues and communication with superiors (Mai-Stiina et al., 2017; Lee \& Kim, 2017) are achieved smoothly so that emotional laborers do not feel emotional and sentimental exhaustion or depersonalization (Lee \& Son, 2016; Kim \& Jung, 2015), as well as consider the emotions or conditions of members so that they can concentrate on customer satisfaction activities. In addition, variables three to five indicate that job performance should be compensated without fail and that in some situations, intangible encouragement and recognition such as praising efforts or ability are more effective than tangible ones such as compensation.

This study identified that turnover intentions, motivation, and job satisfaction act as customer satisfaction factors of customer support centers with an empirical survey conducted with emotional laborers engaged in actual work. The survey results indicate that when the job satisfaction of callers working at SCSCs is higher, their job performance is better, and job performance should be compensated tangibly and intangibly by the enterprise. The survey results also indicate that there are virtuous circles in which compensation increases motivation and reduces turnover intentions.

That is, motivation and job satisfaction, job satisfaction and turnover intentions, and motivation and turnover intentions are not formed by factors or environments independent or different from each other, but are in the same context with each other (maintain high correlations) and are in relationships of virtuous circles in which they complement each other. These are study findings that were not shown in approximately 90 previous domestic and overseas studies investigated for this study and can be said to be a meaningful contribution from an academic aspect as they were derived only in this study, which was an empirical study conducted with callers engaged in emotional labor in customer support centers.

However, the derivation of turnover intentions, motivation, and job satisfaction through literature review and expert opinion surveys conducted with emotional laborers working in customer support centers might have limited the range of factors to respondents that participated in surveys of SCSCs' customer satisfaction factors. Therefore, future studies are planned to be conducted using factor analysis and structural equation models with questionnaires containing more factors.

\section{References}

Abdul Rahman Kadir, Najmi Kamariah, Ariyanti Saleh, \& Ratnawati (2017). The Effect of Role Stress, Job Satisfaction, Self-efficacy and Nurses' Adaptability on Service Quality in Public Hospitals of Wajo. International Journal of Quality and Service Sciences, 9(2), 184-202.

Arun Kumar Tarofder, Seyed Rajab Nikhashemi, S. M. Ferdous Azam, Prashantini Selvantharan, \& Ahasanul Haque (2016). The Mediating Influence of Service Failure Explanation on Customer Repurchase Intention Through Customers Satisfaction. International Journal of Quality and Service Sciences, 8(4), 516-535.

Ashforth, B. E., \& Humphrey, R. H. (1993). Emotional Labor in Service Roles: The influence of identity. Academy of Management Review, 18(1), 88-115.

Ayers, R. S. (2013). Building Goal Alignment in Performance Appraisal Programs. Public Personnel Management, 42(4), 495-520.

Bertelli, A. M. (2007). Determinates of Bureaucratic Turnover Intention: Evidence form the Department of the Treasury. Journal of Public Administration Research and Theory, 17(2), 235-258.

Bishop, B. (2003). When Truth isn't Enough: Authenticity in Public Relations. Public Relations Strategist, 9(4), 22-25.

Bobocel, D. R., \& Zdaniuk, A. (2005). How Can Explanations Be Used to Foster Organizational Justice. Handbook of Organizational Justice, 1, 469-498.

Bradley, G. L., \& Sparks, B. A. (2012). Explanations: If, When, and How They aid Service recovery. Journal of Services Marketing, 26(1), 41-51.

Coo, B. M. (2010). An Empirical Study on Influence Factors of Communication Quality: Focused on The Domestic Courier Industrial Call Center. Korea Logistics Review, 20(1), 153-172.

Choi, S., \& Lee, C. S. (2009). Managing a CSR's Job Satisfaction for Improving Service Quality in Inbound Customer Centers. Korean Journal of Business Administration, 22(6), 3259-3285.

Cho, Y. J., \& Lewis, G. B. (2012). Turnover Intention and Turnover Behavior: Implications for Retaining Federal Employees. Review of Public Personnel Administration, 32(1), 4-23.

Cho, Y. J., \& Lee, J. W. (2011). Perceived Trustworthiness of Supervisors, Employee Satisfaction and Cooperation. Public Management Review, 13(7), 941-965.

Daley, D. M. (2017). Job Satisfaction Versus Job Engagement: A Comparative Analysis on Perception 
of Accountability and Turnover. International Journal of Organization Theory and Behavior, 20(2). 161-192.

Duque, L. C., \& Lado, N. (2010). Cross-cultural Comparisons of Consumer Satisfaction Ratings: A perspective from Albert Hirschman's Theory. International Marketing Review, 27(6), 676-693.

Deci, E. E., \& Ryan, R. M. (1985). Intrinsic Motivation and Self-Determination in Human Behavior. New York, USA. Plenum Press.

Edwards, L. (2010). Authenticity in Organizational Context: Fragmentation, Contradiction and Loss of Control. Journal of Communication Management, 14(3), 192-205.

Farrell, D., \& Rusbult, C. E. (1981). Exchange Variables as Predictors of Job Satisfaction, Job Commitment, and Turnover: The Impact of Rewards, Costs, Alternatives, and Investments. Organizational Behavior and Human Performance, 28(1), 78-95.

Gaertner, S. (1999). Structural Determinants of Job Satisfaction and Organizational Commitment in Turnover Models. Human Resource Management Review, 9(4), 479-493.

Goncalves, P. (2017). Want Successful Employee Communications? Think Like a Marketer. Strategic HR Review, 16(5), 229-233.

Grandey, A., Foo, S. C., Groth, M., \& Goodwin, R. E. (2012). Free to Be You and Me: A Climate of Authenticity Alleviates Burnout from Emotional Labor. Journal of Occupational Health Psychology, 17(1), 1-14.

Gross, J. J. (1998). Antecedent-and Response-focused Emotion Regulation: Divergent Consequences for Experience, Expression, and Physiology. Journal of Personality and Social Psychology, 74(1), 224-237.

Grunig, L. A., Grunig, J. E., \& Dozier, D. M. (2002). Excellent Public Relations and Effective Organizations: $A$ Study of Communication Management in Three Countries. Mahwah, $\mathrm{NJ}$ : Lawrence Erlbaum Associates.

Grunig, J. E. (1992). Symmetrical Systems of Internal Communication, in Grunig, J. E., Dozier, D. M., Ehling, W. P., Grunig, L. A., Repper, F. C., \& White, J. (Eds.), Excellence in Public Relations and Communication Management. Hillsdale, NJ: Lawrence Erlbaum Associates. 531-575.

Harker, P. T. (1989). The art and Science of Decision making: The analytic Hierarchy Process. The Analytic Hierarchy Process: Applications and Studies, 3-36.

Hartline, M. D., \& Ferrel, O. C. (1996). The Manajement of Costumer Contact Service Employees: An Empirical Investigation. Journal of Marketing, 60(4), 52-70.
Hochschild, A. R. (1983). The Managed Heart: Commercialization of Human Feeling. CA: Univ of California Press.

Hom, P. W., \& Griffeth, R. W. (1995). Employee Turnover. $\mathrm{OH}$ : South Western.

laffaldano, M. T., \& Muchinsky, P. M. (1985). Job Satisfaction and Job Performance: A meta-analysis. Psychological Bulletin, 97(2), 251-273.

ITU (1995). ITU-T E.800. Geneva: ITU.

Johnson, M. D., \& Fornell, C. (1991). A Framework for Comparing Customer Satisfaction Across Individuals and Product Categories. Journal of Economic Psychology, 12(2), 267-286.

Judge, T. A., Thoresen, C. J., Bono, J. E., \& Patton, G. K. (2001). The Job Satisfaction-Job Performance Relationship: A qualitative and Quantitative Review. Psychological Bulletin, 127(3), 376-407.

Kang, M. J., \& Sung, M. J. (2017). How Symmetrical Employee Communication Leads to Employee Engagement and Positive Employee Communication Behaviors: The Mediation of Employee-organization Relationships. Journal of Communication Management, 21(1), 82-102.

Kim, G. C., \& Jung, G. J. (2015). The Moderating Effects of Converging Smart Work and Supervisor's Support in the Study of Turnover on Job Satisfaction in Call centers. Journal of Digital Convergence, 13(4), 101-114.

Kim, J. H. (2007). On the Effects of the Key Factors for Service Quality Evaluation on Service Performance in the Call Center. The Academy of Customer Satisfaction Management, 9(1), 155-172.

Kim, J. N., \& Rhee, Y. (2011). Strategic Thinking About Employee Communication Behavior (ECB) in Public relations: Testing The Models of Megaphoning and Scouting Effects in Korea. Journal of Public Relations Research, 23(3), 243-268.

Kim, K. H. (2015). Research on Influence of Trust on Superior on Followers' Knowledge Sharing and Creativity: Through Intrinsic Motivation. Journal of Human Resources Management Research, 22(2), 39-63.

Kim, S. J., Tam, L., Kim, J. N., \& Rhee, Y. (2017). Determinants of Employee Turnover Intention: Understanding the Roles of Organizational Justice, Supervisory Justice, Authoritarian Organizational Culture and Organization-employee Relationship Quality. Corporate Communications: An International Journal, 22(3), 308-328.

Kim, W. B., Rhee, K. Y., \& Lee. G. R. (2012). The Job Environment and Stress of Emotional Workers. Journal of Korean Social Association, 46(2), 123-149. 
Lampinen, M. S., Suutala, E. A., \& Konu, A. I. (2017). Sense of Community, Organizational Commitment and Quality of Services. Leadership in Health Services, 30(4), 378-393.

Lee, H. G., \& Son, Y. G. (2016). A Prediction Model of Call Center Employee's Turnover Behavior: Focusing on Duties and Role of Organizational Communication. The Academy of Customer Satisfaction Management, 18(1), 145-174.

Lee, M. Y., \& Kim, S. B. (2015). A Study on The Relationship Among Non Face-to-face Service Quality, Customer Satisfaction and Reuse Intention Focusing on Voice-to-voice Environment (call center). The Academy of Customer Satisfaction Management, 17(3), 59-80.

Lee, T. W., \& Mitchell, T. R. (1994). An Alternative Approach: The Unfolding Model of Voluntary Employee Turnover. The Academy of Management Review, 19(1), 51-89.

Lee, Y. J. (2017). Exploring the Impacts of Relationship on Employees' Communicative Behaviors During Issue Periods Based on Employee Position. Corporate Communications: An International Journal, 22(4), $542-555$

Lee, Y. J., \& Kim, J. N. (2017). Authentic Enterprise, Organization-employee Relationship, and Employee-generated Managerial Assets. Journal of Communication Management, 21(3), 236-253.

LeRouge, C., Nelson, A., \& Blanton, J. E. (2006). The Impact of Role Stress Fit and Self-esteem on The Job Attitudes of IT Professionals. Information \& Management, 4(3), 928-938.

Löfgren, M. (2005). Winning at The First and Second Moments of Truth: An Exploratory Study. Managing Service Quality, 15(1), 102-115.

Löfgren, M., Witell, L., \& Gustafsson, A. (2008). Customer Satisfaction in The First and Second Moments of Truth. Journal of Product \& Brand Management, 17(7), 463-474.

Mikael, P. (2013). Bank Failures and Regulation: A Critical Review. Journal of Financial Regulation and Compliance, 21(1), 16-38.

Miriam J. (2016). Assessment of The Telephone Service Provision. International Journal of Quality and Service Sciences, 8(1), 72-87.

Mitchell, J. I., Gagné, M., Beaudry, A., \& Dyer, L. (2012). The Role of Perceived Organizational Support, Distributive Justice and Motivation in Reactions to New Information Technology. Computers in Human Behavior, 28(2), 729-738.

Moumtzoglou, A. (2010). The Greek Nurses' Job Satisfaction Scale: Development and Psychometric Assessment. Journal of Nursing Measurement, 18(1), 60-69.
Molleda, J. C., \& Roberts, M. (2008). The Value of 'Authenticity' in 'Global' Strategic Communication: The New Juan Valdez Campaign. International Journal of Strategic Communication, 2(3), 154-174.

Morris, J. A., \& Feldman, D. C. (1996). The Dimensions, Antecedents, and Consequences of Emotional Labor. Academy of Management Review, 21(4), 986-1010.

Negoita, C., Zadeh, L., \& Zimmermann, H. (1978). Fuzzy Sets As a Basis for A Theory of Possibility. Fuzzy sets and systems, 1(3-28), 61-72.

Nugroho, M. K. (2012). Pengaruh Stress Peran dan Kepuasan Kerja Terhadap Komitmen Organisasi Perawat Di RSPI Sulianti Saroso. Jakarta, Indonesia: Tesis, Universitas.

Nyhan, R. C. (2000). Changing the Paradigm: Trust and Its role in Public Sector Organizations. The American Review of Public Administration, 30(1), 87-109.

Oliver, R. L. (1997). Satisfaction-A Behavioral Perspective on The Consume. Irwin, MA: McGraw-Hill.

Oliver, R. L. (1999). Whence Consumer Loyalty?. Journal of Marketing, 63(Special issue), 33-44.

Park, H. I., Kang, H., \& Lee, W. (2012). An Exploratory Study on the Relationship Between Organizational Culture and Motivation, Employee's Performance. Journal of Finance and Accounting Information, 12(3), 23-45.

Park, W. H., Kim, S. G., \& Kim, C. G. (2015). The Effects of Information Systems Quality on the Performance of Emotional Labors : Focused on the Airline Call Centers. Journal of Korea Academy-Industrial Cooperation Society, 16(12), 8800-8811.

Phillips, E. M., Schneider, J. C., \& Mercer, G. R. (2004). Motivating Elders to Initiate and Maintain Exercise. Archives of Physical Medicine and Rehabilitation, 5, 52-57.

Potter, A. (2010). The Authenticity Hoax: How We Get Lost Finding Ourselves. New York, NY: Harper Collins.

Price, J. (1997). Handbook of Organizational Measurement. International Journal of Manpower, 18(4/5/6), 303-558.

Robbins, S. P., \& Judge, T. A. (2013). Organizational Behavior. (15th ed.). MA: Pearson.

Ryzin, G. G., Muzzio, D., Immerwahr, S., Gulick, L., \& Martinez, E. (2004). Drivers and Consequences of Citizen Satisfaction: An application of the American Customer Satisfaction Index Model to New York City. Public Administration Review, 64(3), 331-341.

Saaty, T. L., \& Vargas, L. G. (2013). The Logic of Priorities: Applications of Business, Energy, Health and Transportation. CA: Springer Science \& Business Media. 
Shaw, J. C., Wild, E., \& Colquitt, J. A. (2003). To justify or Excuse? A Meta-analytic Review of The Effects of Explanations. Journal of Applied Psychology, 88(3), 444-458.

Shen, H., \& Kim, J. N. (2012). The Authentic Enterprise: Another Buzz Word, or A True Driver of Quality Relationships?. Journal of Public Relations Research, 24(4), 371-389.

Shin, H. Y. (2014). A Study on the Emotional Labor, Self-Efficacy and Burnout of Call Center Employees. The Academy of Customer Satisfaction Management, 16(1), 159-178.

Shin, S. C., Kim, J. S., \& Kim, D. H. (2015). Relationship Between Occupational Stress and Turnover Intention Among Call Center Counselors. Journal of Korea Academy-Industrial Cooperation Society, 16(2), 1318-1327.

Shostack, L. (1985). Planning The Service Encounter. The Service Encounter, 243-254.

Silayoi, P., \& Speece, M. (2004). Packaging and Purchase Decisions: An Exploratory Study on The Impact of Involvement Level and Time Pressure. British Food Journal, 106(8), 607-28.

Silayoi, P., \& Speece, M. (2007). The Importance of Packaging Attributes: A Conjoint Analysis Approach. European Journal of Marketing, 41(11/12), 14951517.

Stephen, R. (1996). Organizational Behavior: Concepts, Controversies, Applications. 7th edition(Englewood cliffs). NJ: Prentice-hall Inc.

Sub, C. S., \& Lee, S. K. (2016). Effect of Call center Employee's Net Talk Time on Job Stress and Service Quality. Journal of Korea Service Management Society, 17(1), 229-256.

Surprenant, C. F., \& Solomon, M. R. (1987). Predictability and Personalization in The Service Encounter. The Journal of Marketing, 5(2), 86-96.

Swanson, S. R., \& Kelley, S. W. (2001). Attributions and Outcomes of The Service Recovery Process. Journal of Marketing Theory and Practice, 9(4), 50-65.

Tang, Y. T., \& Chang, C. H. (2010). Impact of Role Ambiguity and Role Conflict on Employee Creativity. African Journal of Business Management, 4(6), 869-881.

Van Laarhoven, P. J. M., \& Pedrycz, W. (1983). A Fuzzy
Extension of Saaty's Priority Theory. Fuzzy sets and Systems, 11(1-3), 229-241.

Veber, J. (2000). Management-Základy. Prosperita, Globalizace. Praha, Czech: Management Press.

Vigoda, E., \& Yuval, F. (2003). Managerial Quality, Administrative Performance and Trust in Governance: Can We Point to Causality?. Australian Journal of Public Administration, 62(3), 12-25.

Wang, K., Hsu, L., \& Chih, W. (2014). Retaining Customers After Service Failure Recoveries: A Contingency Model. Managing Service Quality, 24(4), 318-338.

Waters, R. D., Bortree, D. S., \& Tindall, N. T. J. (2013). Can Public Relations Improve the Workplace? Measuring the Impact of Stewardship on The Employer-employee Relationship. Employee Relations, 35(6), 613-629.

Weaver, T. L. (2015). Intent to Exit: Why Do US Federal Employees Leave?. International Journal of Public Administration, 38(6), 442-452.

Yang, K. (2005). Public Administrators' Trust in Citizens: A missing Link in Citizen Involvement Efforts. Public Administration Review, 65(3), 273-285.

Yoon, D., \& Choi, Y. (2011). Analysis of Logistics Network Between Gwangyang Port and China Ports Using Fuzzy-AHP. Journal of Korea Economic, 27(4), 91-107.

Yoon, J. H. (2009). A Study on The Effects Of Motivation And Selling Competence On Performance In Travel Agency. Journal of Human Resources Management Research, 16(1), 103-118.

Zadeh, L. A. (1965). Information and control. Fuzzy sets, 8(3), 338-353.

Zeithaml, V. A., Berry, L. L., \& Parasuraman, A. (1996). The Behavioral Consequences of Service Quality. The Journal of Marketing, 31-46.

Zeithaml, V. A., \& Bitner, M. J. (1996). Service Marketing. International Editions, Singapore: McGraw-Hill, 516-538.

Zorlu, K. (2012). The Perception of Self-esteem and Self-efficacy as Transforming Factors in The Sources of Role Stress and Job Satisfaction Relationship of Employees: A Trial of A Staged Model Based on The Artificial Neural Network Method. African Journal of Business Management, 6(8), 3014-3025. 